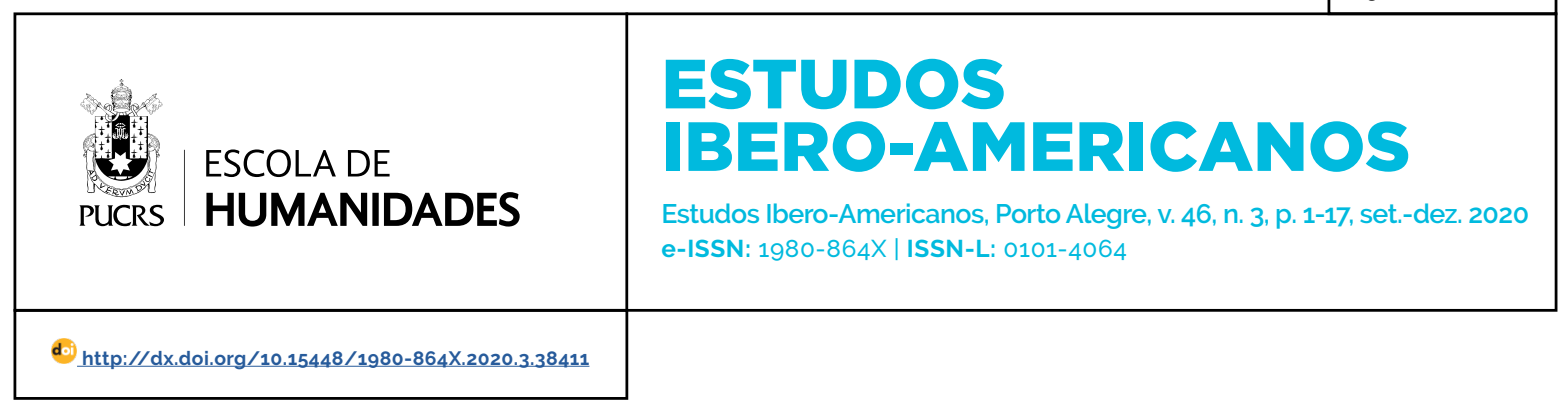

SEÇÃO: TRIBUNA

\title{
O negacionismo renovado e o ofício do historiador
}

\author{
Renewed negationism and the historian's job \\ Renovado negacionismo y el trabajo del historiador
}

\section{Carlos Gustavo Nóbrega de Jesus ${ }^{1}$ orcid.org/0000-0002-1377-8829 superintendencia@promemoria. indaiatuba.sp.gov.br}

Edgar Avila Gandra ${ }^{2}$ orcid.org/0000-0003-4590-2705 edgargandra@yahoo.com.br

Recebido em: 9/6/2020 Aprovado em: $9 / 7 / 2020$. Publicado em: 21/12/2020.

\section{(c) (i)}

Artigo está licenciado sob forma de uma licença Creative Commons Atribuição 4.0 Internacional.
Resumo: O intuito de tal artigo é entender a ampliação do conceito "negacionismo" que, nos últimos anos, não ficou restrito à contestação da existência do Holocausto, mas ampliou-se para outras áreas do saber, tanto dentro como fora da História. Diante de tal perspectiva ampla, salienta-se a repercussão da narrativa negacionista no campo historiográfico, levantando-se a hipótese que a necessidade de se contrapor a tal discurso levou a um embate epistemológico dentro da disciplina, ainda no final dos anos 1990. A partir dai pretende-se averiguar como a narrativa negacionista ganhou legitimidade nos últimos dez anos por meio das redes sociais e da ascensão de políticas conservadoras, salientando a importância do papel ativo dos historiadores e de seu ofício nesse momento marcado pela necessária tomada de posição frente à disseminação de tais leituras proselitistas acerca do passado.

Palavras-chave: Negacionismo. Historiografia. Oficio do historiador. Políticas conservadoras.

Abstract: The purpose of this article is to understand the expansion of the concept of "negationism", which, in recent years, has not been restricted to contesting the existence of the Holocaust, but has been extended to other areas of knowledge, both inside and outside history. Faced with such a broad perspective, the repercussion of the negationist narrative in the historiographic field is highlighted, raising the hypothesis that the need to counter such discourse led to an epistemological clash within the discipline, even in the late 1990s. it is intended to investigate how the negationist narrative has gained legitimacy in the last ten years through social networks and the rise of conservative policies, highlighting the importance of the active role of historians and their craft in this moment marked by the necessary positioning regarding the dissemination of such proselytizing readings about the past.

Keywords: Negationism. Historiography. Historian's craft. Conservative policies.

Resumen: El propósito de este artículo es comprender la expansión del concepto de "negacionismo" que, en los últimos años, no se ha limitado a cuestionar la existencia del Holocausto, sino que se ha extendido a otras áreas del conocimiento, tanto dentro como fuera de la historia. Frente a una perspectiva tan amplia, se destaca la repercusión de la narrativa negacionista en el campo historiográfico, planteando la hipótesis de que la necesidad de contrarrestar dicho discurso llevó a un choque epistemológico dentro de la disciplina, incluso a finales de los noventa. de ahí que se pretenda indagar cómo la narrativa negacionista ha ganado legitimidad en los últimos diez años a través de las redes sociales y el auge de las políticas conservadoras, destacando la importancia del papel activo de los historiadores y su oficio en este momento marcado por el necesario posicionamiento frente a la difusión. de lecturas tan proselitistas sobre el pasado. Palabras clave: Negacionismo. Historiografia. Oficio de historiador. Políticas conservadoras. 


\section{Introdução}

É notório que estamos passando por uma onda conservadora em caráter global, o que nos faz pensar que alguns discursos e posturas ficaram arrefecidos para ressurgirem, recentemente, readaptados ao atual momento político e ideológico dos últimos anos. ${ }^{3}$

A partir de uma análise panorâmica e retrospectiva acerca do desenvolvimento de tais iniciativas podemos salientar que releituras conservadoras a respeito do passado já vêm ganhando espaço, em várias regiões do mundo, há algum tempo, ou seja, desde a crise econômica do petróleo, no final dos anos 1970 (JESUS, 2006, p. 21-34). Dentre esses pode-se destacar o autodenominado "revisionismo histórico", movimento que ganhou fôlego nos anos 1980, mas que pelo seu conteúdo e métodos empregados, foi denominado, a partir dos anos 1990, nos meios acadêmicos, como negacionismo histórico ou negacionismo do Holocausto (JESUS, 2006, p. 34-50). ${ }^{4}$ De acordo com tais pressupostos, o que se pretende nas próximas linhas não é se aprofundar na análise do "evento-matriz da questão do negacionismo - o Holocausto -" (NAPOLITANO; JUNQUEIRA, 2019, p. 1), fruto de outros trabalhos historiográficos (JESUS, 2006; CRUZ, 1997), mas sim buscar entender o seu desdobramento ao longo das últimas décadas, em outros campos da História, como também, em diferentes campos do saber (Geografia, Meio Ambiente, Biologia). Ao longo dos anos, a prática negacionista espraiou-se para os questionamentos dentro do próprio campo historiográfico, principalmente, a respeito do processo da escravidão no Brasil, das torturas e o Golpe Civil-Militar (1964-1985). Já dentre outras áreas do saber, nos deparamos com o atual negacionismo ambiental (no qual podemos evidenciar negação do aquecimento global e do desflorestamento), negacionismo biológico (que se contrapõe à eficácia das vacinas, ) e o negacionismo geográfico (vide o "terraplanismo", grupo que coloca em dúvida o formato do planeta terra).

Diante de tal perspectiva multifacetada que o tema ganhou nos últimos anos, é que pretende-se analisar a repercussão da narrativa negacionista no campo historiográfico, levantando-se a hipótese que a necessidade de se contrapor a tal discurso levou a um embate epistemológico que auxiliou, mesmo de forma involuntária, o amadurecimento de alguns aspectos da disciplina histórica e de suas posturas teóricas e práticas já no final do século XX. Situação que, também, nos leva a averiguar como a narrativa negacionista ganhou legitimidade no tempo presente, influenciando discursos políticos e ideológicos nos últimos dez anos, abarcados pela ascensão da chamada "Nova Direita" e pelos avanços propagandisticos proporcionados pelas midias sociais. ${ }^{5}$

\footnotetext{
3 Deve-se deixar claro que não é nosso objetivo generalizar conceitos tão heterogêneos como, conservadorismo, autoritarismo e direita, por outro lado entendemos que aqui, também, não é o espaço e nem o momento de problematizar tais princípios teóricos. Por isso, quando tratarmos de tais termos estaremos dialogando com Norberto Bobbio e a sua definição de direita em: Direita e Esquerda - razões e significados de uma distinção política, publicado originalmente em 1994.

4 "Os termos "negacionismo/negacionista" têm ampla aplicação em língua portuguesa, em francês e, em menor grau, em espanhol. Em inglês e alemão o termo "negacionismo" não é mais do que marginal: lá usa-se o descritor mais específico, "negação (ou negador) do holocausto": Holocaust Denial (Denier), Holocaust Lugnung (Leugner). Em todos os casos, estes termos têm substituido, com maior ou menor sucesso, o termo "revisionismo", embora seu uso ainda se faça notar com frequência [...] O termo "negacionismo" define ao mesmo tempo um campo político-intelectual internacionalmente articulado e uma prática. Por um lado, descreve uma variante propriamente "Intelectual" de movimentos de extrema-direita do pós-Segunda Guerra Mundial, que busca por meio de textos produzidos na maior parte dos casos com aparência de historiografia, negar que o extermínio planejado e executado durante o Terceiro Reich tenha existido. Por outro lado, o termo diz respeito à própria prática de negação deste extermínio, desde aquela ligada a ação política própria destes movimentos ou aquela dela derivada" (MORAES, 2011, p. 3, 6)

5 Segundo a pesquisadora Vera Alves Cepêda (2018, p. 52-55): "Na última década observa-se no cenário político brasileiro e internacional um fenômeno que ficou conhecido como "nova direita", gerando a movimentação de pesquisadores no esforço de compreenderem esse processo, tanto no Brasil como no mundo. Mas uma investigação dessa natureza apresenta, de saída, pelo menos três importantes problemas: o primeiro, sobre as fronteiras ideológicas que delimitariam o campo da direita, estabelecendo as balizas de sua identidade teórica ou programática; o segundo, sobre os limites temporais que permitiriam a adoção do termo nova direita, com caracteristicas que sustentassem um arranjo distinto daquele concertado em momentos anteriores; o terceiro, originado no reconhecimento de que, embora o momento conservador dos últimos anos seja internacionalmente expressivo, ele varia conforme as configurações nacionais, interagindo com contextos sociais e históricos especificos onde a nova direita assume uma coloração própria [...] [Chama] a atenção a convergência entre conservadorismo e o individualismo mercadológico [...], ressignificando o pensamento conservador, bem como a emergência de uma nova retórica nesse debate: a supressão histórica ou a subversão factual da realidade - o uso da argumentação Fake - como base de uma discussão que se pretende legítima por pertencer ao ambiente acadêmico (prática normalmente associada pela nova direita aos intelectuais de esquerda)". Já Leonardo Gaspary Salles (2017, p. 21-39) define o surgimento do conceito durante o "heterogêneo ciclo de manifestações de 2013". As redes sociais tiveram papel essencial enquanto meio para a organização destes grupos e difusão de suas ideias. Diante disso faz um questionamento pertinente: "[...] pode-se falar de fato na existência em uma nova direita, ou se trata apenas da velha direita com wi-fi? Ou seja, existem novidades substanciais nesses grupos em relação àqueles da direita concebida como tradicional [...]?
} 
Diante de tal situação buscaremos salientar o papel relevante dos historiadores e de seu oficio em função de tais desafios, pois o momento requer uma postura critica, marcadas pela necessária tomada de posição intelectual frente à disseminação de tais leituras proselitistas acerca do passado.

\section{A narrativa negacionista e o ofício do historiador}

Com número não desprezivel de adeptos nos EUA e na Europa, o negacionismo histórico teve sua origem no pós-Segunda Guerra Mundial propondo-se a reinterpretar os acontecimentos de tal combate global, iniciativa que para eles se enquadrava em uma prática revisionista. ${ }^{6}$

No entanto, ao analisar detalhadamente o movimento, nota-se que a principal caracteristica de seus seguidores sempre foi a defesa do antissemitismo e, principalmente, a negação do Holocausto.

[...] os primeiros revisionistas foram aqueles que trabalharam, durante a II Guerra, no serviço de informações das potências aliadas. Na torrente de informações que provinha dos territórios ocupados, havia o verdadeiro, o menos verdadeiro e o falso. Não se colocava em dúvida o sentido do que estava acontecendo, mas era sempre possivel hesitar entre essa ou aquela versão dos acontecimentos [...] (NAQUET, 1988, p. 124-125).

Alguns intelectuais que compartilhavam do então chamado "revisionismo histórico materialista", com o passar dos anos, foram se comprometendo com premissas que forneciam subsidios à negação do extermínio judeu e, no limite. questionariam o próprio genocídio.

Com bases em tal postura, no final dos anos 1970 moldou-se a essência do revisionismo negacionista francês, que daria a base para o negacionismo do Holocausto que percorreria o mundo e ganharia força, principalmente no final da década 1980. Mesmo tendo um caráter um tanto quanto heterogêneo, variando de acordo com as especificidades nas quatro partes do mundo em que passou a ser divulgado, pode-se sintetizar o discurso do movimento a partir dos seguintes argumentos: não houve o genocídio e as câmaras de gás não existiram, o zyklon B era usado especificamente para desinfecção dos presos enfermos; a "solução final" não foi a tentativa de exterminar os judeus, mas sim a de expulsá-los para o Leste europeu; as mortes dos judeus foram naturais, ou ocasionadas por tifo, ou bombardeio aliado. O número de mortos, na opinião da maioria dos negacionistas, não passaria de 200 mil, a Alemanha não é responsável pela Segunda Guerra Mundial, os responsáveis eram os judeus; o genocidio é uma propaganda judia e dos países vencedores da guerra. ${ }^{7}$

Com base em tais informações pode-se dizer que os negacionistas de primeira hora tentaram justificar sua versão dos fatos referentes à Segunda Guerra Mundial como se estivessem praticando uma interpretação crítica do passado. No entanto, ao se aprofundar em uma análise mais precisa de seus escritos, é possivel salientar que, na verdade, o que faziam, desde o início, era aventar versões ideologicamente comprometidas acerca de alguns acontecimentos do porvir, o que por si só não legitimava tal narrativa, pois esse tipo de "construção" passa por determinações caras à história, e aos seus métodos, entre eles a análise crítica de documentos e o cruzamento de fontes, além disso, segundo Jaques Le Goff (1992, p. 51) "compete ao historiador fazer um estudo 'objetivo' do passado sob a sua dupla forma. Comprometido na história, não atingirá certamente a verdadeira 'objetividade', mas nenhuma outra história é possivel".

\footnotetext{
6 No Brasil tal leitura tortuosa do passado chegou no final dos anos 1980, com a Editora Revisão. Criada no Rio Grande do Sul, em 1987 . teve seu primeiro livro editado e escrito pelo próprio fundador, Siegfried Ellwanger, que adotou o pseudônimo de Castan. Holocausto judeu ou Alemão? Nos Bastidores da Mentira do Século, foi lançado em fevereiro de 1988. Nos anos 1990 o livro entrou na lista dos livros mais vendidos entre as publicações negacionistas e Castan envolveu-se em vários processos legais, pelo conteúdo racista dos livros impressos e veiculados por sua editora. Diante disso viu-se obrigado a valer-se de artifícios para contornar proibições legais e passou a divulgar seus escritos na internet (JESUS, 2006).

7 Essas são as linhas argumentativas levantadas por Vidal Naquet (1987, p. 36-46). A maioria dos negacionistas apoiam-se nas contas de Rassinier, segundo as quais $80 \%$ dos judeus do leste se salvaram (Cf. NAQUET, 1988, p. 62). Faurisson estimava um milhão de judeus mortos, sendo que, na sua opinião, metade morreu como soldados e outros devido à "guerra" nos campos. "Quanto ao número de mortos em Auschwitz, judeus e não judeus chegou a cerca de 50.000" (FAURISSON apud NAQUET, 1988, p. 38). Deve-se entender que todos os discursos negacionistas buscam fixar parte de suas argumentações nessas diferenças numéricas para desviar o ponto-chave da discussão que molda a questão do Holocausto, a morte sistemática de judeus e de prisioneiros de guerra.
} 
Na verdade, o que os negadores do Holocausto buscavam era um falso rigor histórico, baseado não na crítica do documento, mas sim na apropriação e na distorção dos fatos pregressos. $O$ que, por sua vez, é o reflexo do momento no qual o movimento floresceu, no final dos 1980, marcado pela valorização do passado e pela aceleração da história, o que levou "as massas dos paises industrializados a ligarem-se nostalgicamente às suas raizes" (LE GOFF, 1992, p. 220). Esse contexto da época, catalisou a tortuosa leitura dos fatos feita por esse grupo, o que chama atenção para o problemático final do século XX e sua relação com a disciplina histórica, pois nesse momento o oficio do historiador foi surpreendido por uma "sequência de novas leituras do passado, plena de perdas e ressurreições, falhas de memória e revisões" práticas que "podem afetar o vocabulário do historiador, introduzindo-lhe anacronismos conceituais e verbais, que falseiam, gravemente, a qualidade de seu trabalho" (LE GOFF, 1992, p. 28).

Para legitimar sua narrativa os negacionistas apropriaram-se da fragilidade do momento e deturparam certas práticas teórico-metodológicas que dizem respeito à história, à linguistica e à filosofia, com destaque para o relativismo histórico e às considerações a respeito da interpretação das fontes. Assim, tal grupo buscava questionar o discurso historiográfico construido sobre o nazismo e demais acontecimentos ligados à cultura política contemporânea, a partir da relativização do valor dos documentos enquanto portadores de verdade, além de argumentarem que os historiadores admitem trabalhar com múltiplas interpretações, sem que se possa considerar uma delas dotada de veracidade absoluta. A partir dessas afirmações genéricas e simplificadoras, propõem-se a desmascarar o que consideram a versão histórica dos vencedores da Segunda Guerra Mundial e dar voz aos vencidos.

É interessante marcar que, para negar o Holocausto, eles mobilizam o positivismo e adotam o empirismo na análise do corpo documental. Assim se, no primeiro momento, desqualificam o trabalho historiográfico por considerá-lo uma arma manipulada por grupos, em seguida contrapõem sua leitura dos episódios, elaborada a partir de uma compreensão linear das fontes e sem admitir que, também, nesse caso, o que se tem é uma versão que poderia estar tão comprometida quanto a que desejam combater. Essa é uma das várias estratégias dos negacionistas para dar uma aparência crítica e cientifica aos seus discursos, buscando, assim, se distanciar de posturas intolerantes, como por exemplo, do racismo e da xenofobia, posicionamentos que já cercearam suas iniciativas, levando tais grupos a terem problemas legais para difusão de suas propostas políticas-ideológicas. ${ }^{8}$

Dentro dessa perspectiva ampla, um problema mais delicado refere-se à questão das "falhas de memória". Com o intuito de marcar a identidade de povos com um passado comum, o final do século XX foi pródigo na recorrência à memória e a grandes feitos do passado. No caso específico dos negacionistas a memória, além de ser vista como objeto, foi utilizada como instrumento de manipulação.

Em momentos de incertezas e revisitações do passado, pode-se afirmar que "o espaço global e o tempo virtual nos têm levado à direção oposta a de sujeitos, nos relegando ao papel de consumidores e de espectadores da história" (CYTRYNOWICZ, 2000, p. 197). Para voltar a ser sujeito dessa história e romper com tal passividade, o trabalho consciente com memória e história, pelo profissional da área, é fundamental. Parece ser óbvio, mas é bom sempre lembrar que tal prática ocorre somente por meio do ofício do historiador, muito bem definido desta forma por Marc Bloch: "Historiador é aquele que busca nos documentos, algo além de explicações explícitas, ou seja, buscam extorquir os esclarecimentos que eles não pretendiam fornecer" (BLOCH, 2001, p. 81), e por outro lado, o historiador deve ter a certeza que os documentos não são portadores da verdade absoluta, as verdades, às vezes, estão naquilo que não está dito, ou seja, no que Certeau (2000, p. 77. grifo nosso) chamou de o "não

8 Essa é uma dentre várias "estratégias da intolerância", salientadas no livro: Antissemitismo e Nacionalismo, Negacionismo e Memória: Revisão Editora e as Estratégias da Intolerância (JESUS, 2006, p. 121-154) 
dito", o que reforça a recomendação de que é a tarefa do historiador encontrar aquilo que está submergido nas suas fontes.

Assim, fica claro que, para se fazer História, é imprescindivel usar os recursos técnicos da profissão, situação que se dá muito mais pela sua prática específica do que somente pela formação acadêmica. Deve-se entender, ainda, que essa prática está atrelada ao fato de como usar o documento e não simplesmente pelo fato de lançar mão do documento, de modo imponderado, prática que caracteriza as iniciativas negacionistas e de movimentos afins, que diligentes na luta pela legitimidade de suas próprias memórias, se apropriaram dos acontecimentos para impor seus interesses puramente políticos, diluidos em críticas de aparência histórica.

Assim, pode-se notar que, de acordo com tais discursos, para dar aparência histórica às suas narrativas, os negacionistas utilizam estratégias diversas, dentre elas, apropriação de documentos e de memórias particulares, que são interpretados de forma deturpada para dar credibilidade às suas teses; e generalizações de posturas metodológicas para questionar o próprio Holocausto enquanto acontecimento (NAQUET, 1988, p. 42). Nota-se, também, a ênfase no problema da "verdade" do conhecimento histórico, afirmação que se constitui em questão central no discurso dos negadores do Holocausto. Assim, manipulando fatos e documentos, tomam a concepção da verdade para si, espoliando a memória.

Não é demais afirmar que, a partir do final dos anos 1980, houve uma forte tendência de críticos literários e de parte da comunidade de historiadores alertarem para a tênue linha que distinguia ficção e verdade, impulsionando discursos ideológicos e tendenciosos, como o dos negacionistas. Assim, ao se apropriarem, de forma simplista, da ideia de que não há parâmetro para a verdade histórica, os negacionistas reivindicavam um lugar para seu discurso, ou para sua "verdade" dentro do campo histórico. Eric Hobsbawm trata o problema de tal forma:

A história como ficção, contudo, recebeu um reforço acadêmico de uma esfera inesperada:

\begin{abstract}
'o crescente ceticismo concernente ao projeto iluminista de realidade'. A moda do que é conhecido (pelo menos no discurso acadêmico anglo-saxão) pelo vago termo "pós-modernismo", felizmente não ganhou tanto terreno entre os historiadores quanto aos teóricos de literatura e da cultura e antropólogos sociais, mesmo no E.U.A., mas é relevante a questão em pauta, já que lança dúvida sobre a distinção entre fato e ficção, realidade objetiva e discurso conceitual. É profundamente relativista. Se não há nenhuma distinção clara entre o que é verdadeiro e o que sentimos ser verdadeiro, então minha própria construção de realidade é tão boa quanto a sua ou a de outrem, pois "o discurso é produtor desse mundo, não o espelho" (HOBSBAWM, 2000, p. 286).
\end{abstract}

Os estudos polêmicos de Hayden White (1987. p. 58-82) que chamaram atenção para o caráter discursivo da História, foram alvo de várias críticas que reconhecem a necessidade do historiador estar atento para os aspectos propriamente narrativos de seus textos, não obstante, abdicando da evidência e das especificidades da produção de saber na área. Neste sentido Chartier (1994. p. 102) posicionou-se como o principal detrator da postura de White: "[...] mesmo que escreva de uma forma literária, o historiador não faz literatura, e isto pelo fato de sua dupla dependência. Dependência em relação ao arquivo, portanto em relação ao passado do qual ele é vestígio".

A propensão de White ao relativismo e as consequências dessa tendência na interpretação dos documentos foi amplamente discutida também por Carlo Ginzburg (1992, p. 12), o historiador italiano criticou a tolerância de White, lembrando que suas considerações podem dar credibilidade a qualquer discurso, inclusive aos dos negacionistas. Ginzburg (1992, p. 12) criticou o posicionamento de White quando esse afirmou que "devemos estar atentos contra um sentimentalismo que nos conduziria a rechaçar uma concepção só por ter sido relacionada com ideologias fascistas" (WHITE, 1987, p. 74-75). Esse fragmento, do texto "The Politics of Historical Interpretation", presente em The Content of the Form (1987), fez Ginzburg (1992, p. 12) concluir que, se o processo narrativo negacionista de Faurission provasse alguma vez ser eficaz, seria considerado por White como verdadeiro (GINZBURG, 1992, p. 13).

As considerações de Ginzburg alertam, ainda, 
para as questões éticas colocadas pelo Holocausto. Se grande parte dos documentos do genocidio foram destruidos pelos nazistas, os testemunhos de sobreviventes dos campos de concentração, como o de Primo Levi, não podem ser descartados. O raciocínio do historiador italiano é pertinente, pois como se viu, a questão da memória dos sobreviventes dos campos de concentração é uma das fontes descartadas no método de pesquisa empregado pelos negacionistas.

Devido às suas conclusões controversas e aos seus métodos derivados de manipulações do campo da história, o negacionismo suscitou inevitáveis discussões no meio acadêmico no final da década de 1990 (FINKELSTEIN, 2000; DE DECCA, 2001, p. 25).

As discussões, porém, não foram circunscritas às publicações e congressos. A historiadora Deborah Lipstadt chegou a ser alvo de um processo movido pelo negacionista David Irving, processo que ganhou grande repercussão na mídia e, inclusive, tendo sua história representada no filme Negação (do original em inglês, Denial), lançado em 2016.9 Toda a situação fez a historiadora destacar a relevância de discutir a negação do Holocausto:

Necessitamos nos ocupar da questão (o negacionismo) porque as forças da razão são vulneráveis e porque a sociedade é suscetivel às ideias aberrantes. As pessoas que habitam reinos imaginários e irracionais, a exemplo de pessoas que negam a existência de Auschwitz, criaram correntes de opinião poderosa, em termos históricos, como o próprio nacional-socialismo (LIPSTADT apud VILMAR, 2000, p. 103-121, grifo nosso).

Pode-se dizer que tais inquietações ajudaram a compelir um posicionamento mais firme da comunidade historiográfica em face às especificidades dos métodos e práticas negacionistas, auxiliando ao historiador do século XXI a olhar com uma certa reserva para o furacão que representou "a viragem antropológica" (BURKE,
1997. p. 94-107) da historiografia, do final dos anos 1980. Com isso, o que era considerada uma disputa por espaço dentro do campo acadêmico, se tornou uma reflexão de fundo sobre a própria sobrevivência da disciplina histórica e de suas especificidades. O que reviveu, com outros olhares, a leitura de François Dosse sobre a fragmentação da história, advinda de tal "viragem" cultural. O historiador que a determinou de "história em migalhas", afirmou que essa possivel construção de um passado histórico ou de seus acontecimentos, defendida pelos historiadores dos Annales, poderia dar um caráter relativista à disciplina (DOSSE, 1994, p. 67).

Mesmo concordando-se em partes com Dosse (1994), deve-se destacar que a questão deve ser direcionada para um melhor uso e entendimento das fontes e métodos históricos. Por exemplo, não se deve esquecer que o percurso da escola francesa contribuiu para que a questão da memória na história fosse reavaliada. Ao tomar a memória como objeto da história, a historiografia francesa recorreu ao cruzamento entre a história oral "de tons antropológicos que reabilitava a construção do vivido, e a sociologia da memória inaugurada por Halbwachs", (RIOUX, 1998, p. 31) para quem a memória sempre resultava da convivência social. Tal diálogo possibilitou perceber que a memória ajudaria a efetivar a relação passado e presente, pois a ela "confere-se atributos de atividade natural, espontânea, desinteressada e seletiva, que guarda do passado apenas o que lhe pode ser útil para criar um elo entre presente e passado" (RIOUX, 1998, p. 31).

Inspirado em tal discussão, Pierre Nora distinguiu História e Memória, defendendo que a História é a disciplina responsável pela problematização do passado e da memória, pois "desenvolve-se como exercício regrado da memória, que busca a reconstituição do passado sem lacunas e sem falhas" e, mesmo sendo, muitas vezes, "problemática e incompleta" (NORA, 1989,

\footnotetext{
9 Dirigido por Mick Jackson e escrito por David Hare, o filme foi baseado na própria obra literária de Deborah Lipstadt History on Trial: My Day in Court with a Holocaust Denier. A historiadora Deborah Lipstadt foi acionada pelo negacionista David Irving, acusada de ter abalado a reputação do historiador citado com o livro Denying the Holocaust (1993). Lipstadt foi absolvida em abril de 2000 . Irving fundamentou sua acusação nas memórias que Adolf Eichmann escreveu na Argentina. O negacionista insistia em afirmar que comprovaria a inexistência das câmaras de gás, estratégia que não deu certo, pois Deborah Lipstadt conseguiu que o governo israelense liberasse para a justiça diários originais que Eichmann escreveu durante sua prisão em Jerusalém.
} 
p. 25) é fundamentada em um discurso crítico, ao contrário da memória, que seria resumida em: "[...] lembranças enevoadas, telescópicas, globais e flutuantes, particulares ou simbólicas, sensiveis à todas as transferências, censuras ou projeções [...]" (NORA, 1989, p. 25-26).

Tal diferenciação se mostrou essencial para as discussões teórico-metodológicas do campo da história no final do século $X X$, pois o profissional da área (foi impelido a se posicionar perante as disputas pela memória, sinais dos tempos de pós-modernidade no qual tais enfrentamentos ganharam conotações políticas e ideológicas. Dessa forma, coube ao historiador, no exercer do seu ofício, se colocar abertamente contra as críticas feitas pelos negacionistas às memórias de sobreviventes judeus, principalmente, quando afirmaram que tais memórias são apropriações utilizadas para atender aos interesses de um grupo, o sionismo judaico mundial, que busca vultosas indenizações, dramatizando e intensificando o Holocausto. Não se pode negar que há grupos judaicos que se apropriam do Holocausto para forjar pesadas indenizações, mas a generalização de tal prática como se faz na narrativa negacionista, envolvendo toda comunidade judaica, deixa clara não uma crítica histórica, mas um forte antissemitismo, marcado por uma ideologia intolerante.

\section{O negacionismo ampliado e o papel do historiador em tempos de "pós-verdade"}

As análises críticas à narrativa negacionista feitas no campo da disciplina histórica, entre o final da década de 1990 e os primeiros anos do novo século, indicaram que havia em curso uma batatha de valorização da memória, a partir das quais grupos tentavam impor suas leituras do passado a partir de pretensas revisões, "tendo como um dos objetivos a afirmação e revisão das memórias e dos ressentimentos" (ANSART, 2001, p. 32).

Aos poucos, pode-se notar que as estratégias de discurso utilizadas pelos negacionistas do Holocausto passaram a dar subsidios às refutações de outros acontecimentos históricos.

Em caráter nacional, pode-se se estabelecer como marco, as reverberações instigadas pela a criação da Comissão da Verdade, instituida pela Lei Federal número 12.528/2011, de 18 de novembro de 2011 que, em 2012, nomeou uma comissão para apurar as violações dos direitos humanos cometidos na Ditadura Civil Militar brasileira (1964-1985). Segundo a historiadora Lucileide Costa Cardoso (2011, p. 134) quando começaram os trabalhos, os militares herdeiros do processo de tomada de poder se posicionaram por meio do Clube Militar. A instituição localizada no Rio de Janeiro "tornou-se porta-voz oficial da memória dos militares golpistas. Além de pronunciamentos, uma série de outros eventos comemorativos: missas, festas, cursos, medalhas e placas insistiam em perpetuar 'a revolução de 64' como lugar da memória" (CARDOSO, 2011, p.134). O brigadeiro Ivan Frota, presidente do Clube da Aeronáutica, informou que procurara o presidente da Comissão Nacional da Verdade para encaminhar, em nome da Academia Brasileira da Defesa, documentos, livros e revistas como "'subsídios para a apreciação isenta dos fatos', para que o grupo possa ter outras fontes de informações, e assim 'conseguir preservar a verdade' em relação ao que ocorreu durante a revolução de 1964" (DIAS, 2013, p. 88). Tal iniciativa justificou o brigadeiro Frota, tinha o objetivo de ajudar a comissão a ver o "outro lado da história, já que ela, a Comissão, tem trabalhado em uma direção única" (DIAS, 2013, p. 88). Nota-se que havia uma disputa para legitimar uma memória que pudesse justificar o golpe, por isso, os depoentes da Comissão da Verdade insistiam que "havia uma guerra revolucionária, comunista, em marcha no Brasil" (D'ARAUJO; SOARES; CASTRO, 1994a, p. 12). Nesse sentido, 1964 é visto como um contragolpe ao golpe de esquerda que viria, provavelmente assumindo a feição de uma "república sindicalista" ou "popular" (D'ARAUJO; SOARES; CASTRO, 1994a, p. 12).

O discurso de tais militares se aproximava ao dos negacionistas do Holocausto, pois ambos negavam fatos limites, ou seja, acontecimentos que estão comprovados empiricamente, como por exemplo, a tortura, o golpe e a própria ditadura. 
No entanto, o que ambos os grupos buscavam era negar a memória dos seus oponentes, para legitimar suas próprias memórias, construídas segundo interesses políticos e ideológicos, provocando novo embate pelo passado. Se escoravam em máximas simplistas e generalistas, como a de que as rememorações dos judeus ou dos torturados pela ditadura civil-militar não estavam imunes às emoções dos ressentimentos ocasionados pelos traumas ocorridos, o que é mais do que evidente pois, a memória forma-se de tais "feridas abertas, interrogações atuais e palpitantes sobre certos períodos que 'não passam'", (ROUSSO, 1998, p. 95) possibilitando, a partir da experiência de cada um, vários olhares sobre um mesmo tema, o que, por sua vez, não inviabiliza a veracidade dos acontecimentos que vivenciaram.

Por isso, pode-se dizer que o momento tornou, mais agora do que nunca, a historicização da memória como ato essencial ao ofício do historiador. Inclusive, saber articulá-la, mas de modo algum anulá-la, seria sua tarefa primeira, pois como afirma Jacy Alves Seixas (2001, p. 55), as memórias nas últimas décadas são apropriadas para "substituir uma função mítica e utópica [...], cumprindo funções que "até recentemente (década de 60, provavelmente...) as utopias históricas preenchiam".

Assim, se há uma luta pela memória, é de extrema relevância para a história que os sobreviventes do Holocausto e as vítimas do Regime Civil Militar brasileiro sejam ouvidos e que suas experiências sejam consideradas, para que no futuro, memórias ideologicamente forjadas, utilizadas como instrumentos de discurso, não venham requerer um lugar na história.

Por outro lado, para alguns, a situação se torna mais delicada, pois tais problemáticas estão na seara de uma história "que fere, que faz sangrar". Ao utilizar de uma metáfora orgânica, Nora (1989, p. 53) exemplifica: "quando se trabalha com carne viva, ela reage e sangra", pois está em uma linha tênue "que separa a história hoje viva da história hoje morta". Ou seja, estamos salientando aqui o debate no campo da História do Tempo Presente. no qual o distanciamento é quase nulo e há envolvimento dos sobreviventes ou de seus parentes com o fato. Pode-se afirmar, nesse caso, mais uma vez, que discussões teóricas metodológicas como essas, estimularam o amadurecimento teórico da historiografia dos últimos anos, pois por mais que, ainda, os historiadores ortodoxos reprovem, está se superando a necessidade cartesiana de distanciamento temporal para garantir uma análise histórica mais isenta. Segundo Marieta Moraes Ferreira (2000, p. 4) o recuo do tempo não garante essa objetividade pretendida, pois o historiador e o próprio conhecimento histórico são tributários de seu tempo.

Para trabalhar com todas essas situações, a tarefa do historiador deve ser cuidadosamente articulada por meio de seu método histórico, pois, se as verdades da história, apesar de tudo, são relativas e parciais, o mesmo não acontece com o método histórico, que têm suas particularidades e especificidades, mas não variam no seu objetivo final que é a abordagem critica das fontes (ABREU, 1996, p. 7).

Nesse caso é que se estabelece a relevância social do ofício do historiador, pois ele tem a competência de instrumentalizar o recurso técnico, por meio de seus métodos, e mostrar que as narrativas como as dos negacionistas, não são meras interpretações da história, mas sim, na verdade, a negação da própria História. "O fato de que os fornos nazistas tenham existido ou não pode ser estabelecido por meio de evidências. Uma vez que isso foi estabelecido, os que negam sua existência não estão escrevendo história, quaisquer que sejam suas técnicas narrativas" (HOBSBAWM, 2000, p. 289-290).

Essa conscientização de seus métodos e práticas, assim como a relevância social e politica do seu trabalho faz o historiador e seu ofício se tornarem cada vez mais necessários, pois nos últimos anos a violência e os abusos da escravidão africana e o tráfico atlântico de seres humanos, por mais descabido que isso possa parecer, também passaram a ser questionados.

Tal posicionamento "simplesmente ignora a responsabilidade de portugueses no tráfico negreiro ocorrido entre os séculos XVI e XIX e omite que o modelo de escravidão comercial que promoveu a colonização das Américas foi criado pelos 
europeus"10 Posição compartilhada pelo próprio Presidente da República do Brasil, Jair Bolsonaro, que em entrevista quando era ainda candidato, afirmou: "Se você for ver a história realmente, o português não pisava na África, era [sic] os próprios negros que entregavam os escravos" (informação verbal). ${ }^{11}$ Segundo Marina de Mello e Souza (2019, p. 1, 3, 7), as afirmações de Bolsonaro são esvaziadas de críticas historiográficas, pois teve

[...] a intenção de atribuir inteiramente aos africanos a responsabilidade pelo tráfico de pessoas escravizadas. Mas é interessante notar como a evocação à história ("se você for ver a história realmente") é peça chave na sua frase telegráfica, ou tweetgráfica. A história é a comprovação da veracidade da afirmação, que entretanto é falsa. Pois foram justamente os portugueses que, tirando os árabes, pisaram mais fundo na África, impenetrável ao estrangeiro até os novecentos, e se estabeleceram a partir do século $X V$ em algumas regiões do continente e das ithas, como a Guiné e Cabo Verde, Angola e São Tomé, Moçambique e a Zambézia [...] não há como sustentar a afirmação de que os portugueses não pisavam na África, mesmo que em um inédito momento de sutileza o autor da frase tenha recorrido a uma imagem, estando de fato se referindo a que os portugueses não capturavam diretamente os africanos escravizados, pois justamente eles, capturaram sim. Não vem ao caso aqui enumerar a vastissima historiografia sobre o tráfico de escravizados e sobre a história da África que se debruçou sobre o envolvimento dos africanos com o comércio de gente, e principalmente sobre as razões que levaram a esse comércio, que mesmo durante os séculos nos quais ocorreu nunca foi unanimidade, provocando entre os eruditos e os legislado- res discussões acerca de sua legitimidade. [...] Desde a mencionada entrevista do então candidato a presidente da república muita água rolou sob a ponte e hoje a segurança com que a família Bolsonaro, seus seguidores e seu guru afirmam os maiores absurdos, e por isso são aplaudidos por cerca de $30 \%$ do eleitorado, é um jogo de cena muito bem orquestrado que tem deixado o resto da plateia que os assistem bestializada, para recorrer a uma ideia firmada pela melhor historiografia brasileira. Mas não a nós historiadores, que por isso mesmo estamos na linha do tiro. Vamos continuar refletindo, analisando, interpretando e ensinando nosso ofício, e agindo dentro das possibilidades de cada um de nós em prol da construção do conhecimento, que além de saciar a curiosidade nos dá instrumentos para atuar de forma transformadora na sociedade da qual fazemos parte.

Antes mesmo de Bolsonaro tecer tal comentário, discursos semelhantes já eram fortemente disseminados por meio da internet. Como exemplo pode-se destacar o grupo "Brasil Paralelo", empresa brasileira fundada em 2016, em Porto Alegre, que se intitula como "mídia independente", mas que, na verdade, divulga conteúdos negacionistas e anticientíicos por meio de vídeos que distorcem fatos históricos acerca justamente da escravidão, colonização do Brasil e da ditadura civil militar. ${ }^{12}$ É manifesto, também, que o órgão se alinha de forma totalmente ideológica, com a atual política de extrema direita brasileira, promovendo teorias conspiratórias e negacionistas alinhadas a Olavo de Carvalho, conselheiro do atual Presidente Jair Bolsonaro. ${ }^{13}$

O NEGACIONISMO histórico como arma política. Carta Capital. São Paulo, 3 abr. 2019. Seção Política. Disponível em: https://wwww. cartacapital.com.br/politica/o-negacionismo-historico-como-arma-politica/. Acesso em: 17 maio 2020.

${ }_{11}$ BOLSONARO, Jair. Entrevista. (30 jul. 2018) Entrevistador: Frei David. São Paulo. TV Cultura, 2018 Entrevista concedida ao Programa Roda Viva.

12 Sobre tal característica e a auto definição como "mídia independente" do site, conferir: BRASIL PARALELO. brasilparalelo.com.br. 2016c. Disponivel em: https://site.brasilparalelo.com.br/sala-de-transmissao-a-patria-ducadora/?gclid=EAlalQobChMl2JKk3MO76QIVhBGRCh2gfAYPEAAYASAAEgKEyPD_BwE\&ref=W25057821S. Acesso em: 18 maio 2020. Segundo Fernando Nicolazzi, Professor do Departamento de História da UFRGS, "Olavo de Carvalho é o ideólogo que, menos por talento intelectual e mais pela disposição autoritária de seus seguidores, conseguiu estabelecer de forma bastante difusa os principios de uma hegemonia que se ampara em dois elementos básicos: a disseminação do medo e o cultivo do ódio [...] o Olavismo se espalhou pelos mais variados interstícios sociais e. com a ascensão de Bolsonaro à presidência, foi tornado política de Estado para a área da cultura, da educação, do meio ambiente e da política externa. Entre as pessoas físicas e juridicas que se ocupam de espalhar a palavra de Olavo pelo país, encontra-se a produtora Brasil Paralelo. Como se sabe, a empresa é responsável pela criação de conteúdos de história que conciliam falsificação documental. distorções interpretativas, preconceito religioso, inverdades históricas e desonestidade intelectual. NICOLAZZI, Fernando. Brasil Paralelo, uma empresa colaboracionista. Sul 21. 17 jan. 2020. Disponível em: https://www.sul21.com.br/opiniaopublica/2020/01/brasil-paralelo-uma-empresa-colaboracionista-por-fernando-nicolazzi/. Acesso em: 18 maio 2020.

13 Brasil Paralelo divulgou em 17 de março de 2019 a entrevista que o Ministro das Relações Exteriores, Ernesto Araújo declarou a estapafúrdia tese de que o nazismo é de esquerda, "discurso que esteve em alta nas midias sociais brasileiras durante as eleições e teve repercussão internacional, principalmente no próprio meio acadêmico alemão. Segundo a Historiadora Stefanie Schüler-Springorum, diretora do Centro para Pesquisa sobre Antissemitismo da Universidade Técnica de Berlim, tal discurso é "altamente problemático diplomaticamente e um absurdo cientificamente". Posição compartilhada pelo Historiador Wulf Kansteiner, da Universidade de Aarhus, que afirmou que os nazistas jamais seguiram politicas de esquerda [...], da perspectiva acadêmica histórica, essa declaração é uma asneira", para ele tanto o entrevistador quanto o ministro "jogam com a palavra totalitarismo e, durante sua argumentação, Araújo tenta com ela traçar uma fronteira entre o nacionalismo, que seria algo bom, e o socialismo, que seria algo ruim". NEHER, Clarissa. "Nazismo de esquerda": o absurdo virou discurso oficial em Brasilia. Deutsche Welle. 28 mar. 2019. Disponivel em: https://www.dw.com/pt-br/ nazismo-de-esquerda-o-absurdo-virou-discurso-oficial-em-bras\%C3\%ADlia/a-48060399. Acesso em: 19 mar. 2020. 
Postura controversa frente à questão do trabalho escravo também pôde ser verificada no discurso do recém empossado Presidente da Fundação Cultural Palmares, o jornalista Sérgio Nascimento de Camargo que em novembro de 2019 negou a existência de racismo no Brasil. Negro, militante de direita, ele utilizou as redes sociais para defender o fim do feriado da Consciência Negra, criticar manifestações culturais ligadas à população negra e atacar diversas personalidades negras, a quem sugere que sejam mandadas para a África, afirmando, ainda, "que a escravidão foi 'terrivel, mas benéfica para os descendentes' porque negros viveriam em condições melhores no Brasil do que na África". Também já disse sentir "vergonha e asco da negrada militante".14

Este negacionismo repaginado, que ganhou força com a ascensão do pensamento, e a política conservadora nacional dos últimos anos, ou seja, a chamada "nova direita", o advogado Bruno Antônio Barros Santos denominou, "negacionismo gourmetizado":

[...] com as mídias sociais do mundo virtual, intensificou-se a produção discursiva de uma espécie de negacionismo gourmetizado, aparentemente sedutor, mas profundamente enganoso. Um lugar-comum que cultiva a negação da história por meio da simplificação da linguagem, ao mesmo tempo em que empurra as problematizações para o campo "estéril" da perda de tempo. É a lógica da produção mercadologizada do pensamento, submetendo o mundo da vida à ótica utilitária daquilo que pode produzir valor na lógica do capital. Em outras palavras: discutir escravidão, desigualdade racial e racismo seriam coisas de esquerdista desocupado e improdutivo [...] E o negacionismo gourmetizado atual é ostentador, através de inúmeras páginas de mídias sociais (ex: fanpages), capitaneadas por uma militância engajada e profissionalizada na fabricação de mentiras, Fake News e pós-verdade. Esse engajamento consegue produzir milhares de likes e viraliza através de uma linguagem simplificada que penetra facilmente nas pessoas [...] não tolera a convi- vência com os fatos, por isso apela para uma retórica de espantalhos em torno da pecha do "mimimi" e do "coitadismo". O negacionismo gourmetizado sabe que, no confronto de dados, a derrota de sua frágil negação é iminente. Dai o enquadramento e o rotulamento dessas discussões criticas e problematizadoras como algo de 'esquerdista', 'comunista' e 'vitimista'". 15

De forma semelhante com que ocorreu nos anos 1990, a ascensão de tais discursos conservadores de extrema direita dos últimos anos chamaram a atenção da comunidade historiográfica, também, para as ameaças que tais propostas representam para a credibilidade do seu campo. Como pode-se notar, o termo "negacionismo" que teve como seu "evento-matriz" a questão da negação do Holocausto passou a ser difundido para outras áreas dentro da disciplina histórica, como questionamentos em torno da História indígena, "da História africana e da escravidão, o impacto das categorias de raça e gênero nos estudos históricos, os revisionismos em contextos internacionais (com foco na questão da Inquisição e a perspectiva das direitas estadunidenses) e, por fim, os negacionismos e revisionismos em torno das ditaduras latino-americanas".16

Assim, por mais que tentemos nos distanciar de tal polêmica a fim de não dar voz às tais leituras oportunistas, nunca se precisou tanto do posicionamento da comunidade historiográfica como agora, pois tais releituras do passado estão ganhando cada vez mais legitimidade institucional em países governados por grupos de direita e extrema direita, entre eles o Brasil. Ainda, termos como "pós-verdade" e "Fake News" ganharam notoriedade, contribuindo ainda mais para o arrocho do conceito de verdade do até então seguro e objetivo modelo epistemológico da ciência, que, por sua vez,já tinha começado a ser relativizado desde

\footnotetext{
14 CAMARGO, Sergio Nascimento apud MENDONÇA, Ana Carolina. Novo presidente da Fundação Palmares nega a existência de racismo no Brasil e manda artistas 'de volta para África'. Estado de Minas. Belo Horizonte, 27 nov. 2019 (Seção-Política). Disponivel em: https:// www.em.com.br/app/noticia/politica/2019/11/27/interna_politica,1104183/novo-presidente-da-fundacao-palmares-nega-a-existencia-de-racismo-no-b.shtml. Acesso em: 22 maio 2020.

15 SANTOS, Bruno Antonio Barros. O negacionismo do racismo. Justificando: mentes inquietas pensam Direito. 21 nov. 2018. Disponível em: https://Www.justificando.com/2018/11/21/o-negacionismo-do-racismo/. Acesso em: 17 maio 2020

16 NAPOLITANO, Marcos; JUNQUEIRA, Mary Anne. Negacionismos e Revisionismos: o conhecimento histórico sob ameaça". Síntese dos debates e posicionamentos surgidos no evento promovido pelo Departamento de História da FFLCH / USP - Universidade de São Paulo). Disponivel em: https://edisciplinas.usp.br/pluginfile.php/5207773/mod_folder/content/O/NAPOLITANO\%2C\%20Marcos\%3B\%20 JUNQUEIRA\%2C\%20Mary\%20Anne.\%20Como\%20historiadores\%20e\%20professores $\% 20$ devem $\% 20$ lidar\%20com\%20negacionismos\%20 e\%20revisionismos..pdf?forcedownload=1. Acesso em: 20 maio.2020
} 
O final do século XX pelos pós-modernistas. ${ }^{17}$

No campo da História, a discussão entre fato e ficção acabou dando lugar às mais deturpadas versões acerca dos acontecimentos do passado, iniciativas derivadas de profissionais fora do campo do conhecimento histórico, que reivindicavam para si, mesmo sem ter o domínio do ofício do historiador, a legitimidade acerca do conhecimento histórico. O resultado de tal situação foi uma enxurrada de produções bibliográficas acerca do passado voltadas totalmente para o mercado, o que tirava destas todo e qualquer compromisso com o método historiográfico.

Se no final dos anos 1990, Eduardo Bueno já se utilizava de uma produção anedótica e sem problematização teórica, nas primeiras décadas do século XXI assistimos aos fenômenos de vendas: 1808 (2007) e 1822 (2010) de Laurentino Gomes (2007); e os Guias politicamente incorreto da História do Brasil (2009) e da América Latina (2011), de Leandro Narloch (2009).

A respeito dos escritos de Laurentino Gomes, Jurandir Malerba (2014, p. 37) salienta, "sob a perspectiva da história crítica, suas fragilidades são gritantes", já que utiliza semelhante estratégia narrativa de Eduardo Bueno, pois a "[...] fórmula é a mesma: história no formato de saga; nas veladas explicações históricas, ênfase na psicologia dos personagens, que são condenados ou absolvidos como heróis ou parvos de mau-caráter". Tais narrativas de fácil leitura logo cativaram o grande público, mas coube a Narloch com base em um sensacionalismo sem limites obter o maior sucesso no mercado. É notório na leitura de seus livros um ponto em comum, a radicalização da apropriação do passado a partir de valores con- servadores e preconceituosos:

Sob a bandeira do "politicamente correto", mal se disfarça uma visão altamente conservadora, quando não reacionária, retrógrada, eurocêntrica e preconceituosa da/sobre a história do Brasil. Por exemplo, em relação a negros e índios, Narloch reproduz uma interpretação típica das classes senhoriais brasileiras do século XIX segundo a qual a construção do Brasil foi obra de europeus (portugueses) e o Brasil fez-se quase que apesar da existência de negros e indios [...] Um dos momentos mais delicados da obra é a referência à ditadura civil-militar que manchou o Brasil entre 1964 e 1985. É cada vez mais comum que novos estudos promovam uma releitura menos ideologizada do periodo e que cada vez se fale menos em "mocinhos" e "bandidos", como sugere Narloch. Mas o autor toma abertamente um só partido da dicotomia, um partido pró-militar (MALERBA, 2014, p. 37-38).

Além de uma leitura sensacionalista do passado com vistas a sucessos editoriais, os três autores mencionados têm em comum a crítica à escrita dos historiadores profissionais, visto por eles como arrastada e rebuscada, não destinada ao grande público, ficando, por isso restrita ao interior da academia. (MALERBA, 2014, p. 36). Por mais que saibamos que essa é uma justificativa oportunista e desonesta, e que a preocupação de tais autores passou longe da popularização do conhecimento histórico, talvez tenhamos que fazer um exame de consciência o quanto nós historiadores não contribuimos para construção de tal cenário, principalmente não enxergando que tais manifestações estavam além de uma oportunidade de mercado, mas sim, eram os primeiros sinais dos tempos sombrios que estavam por vir, baseados na relativização extrema do conceito de História em nome de um posicionamento político e ideológico conservador.

A surpresa a respeito do sucesso dessas pu-

\footnotetext{
17 Steve Tesich utilizou pela primeira vez o termo pós-verdade na revista semanal The Nation, em 1992 para explicar relação entre o incidente Watergate (escândalo que levou a renúncia do então presidente dos Estados Unidos da América, Richard Nixon) com fatos que ocorreram após a Guerra do Vietnã. "Na ocasião, o autor relatava que o escândalo Watergate fez com que a população americana não desejasse mais más-notícias. Não importando o quão verdadeiras ou importantes elas fossem criar uma pós-verdade era mais importante. desde que, essa pós-verdade, fosse o que a população gostaria de ler. Posteriormente, por mais doze anos o termo continuou "escondido" até ganhar grande repercussão ao ser o tema de uma coluna do jornal The Economist. Na ocasião, o jornal chamava atenção ao grande perigo causado por uma sociedade onde a verdade é um item secundário. Utilizando como exemplo o mundo fantástico de Donald Trump onde a Barack Obama não é americano e fundou o Estado Islâmico" (ALVES; BOLESINA, 2018, p. 2-3). [...] Em 2016 o Dicionário Oxford que definiu "pós-verdade" como a palavra do ano em 2016, ela pode ser definida por um adjetivo relacionado ou evidenciado por circunstâncias em que fatos objetivos têm menos poder de influência na formação da opinião pública do que apelos por emoções ou crenças pessoais". POST-TRUTH. In: Oxford Dictionaries. [2017]. Disponivel em: https://www.lexico.com/definition/post-truth. Acesso em: 1 jun. 2020. (tradução nossa). Já Fake News, pode ser definido como a "divulgação de notícias falsas [...] ou ser conceituado como a disseminação, por qualquer meio de comunicação, de notícias sabidamente falsas com o intuito de atrair a atenção para desinformar ou obter vantagem política ou econômica". Trata-se de fenômeno consolidado e que se verifica em todo o planeta. Alguns estudos chegam a atribuir a vitória de Donald Trump, eleito à presidência dos Estados Unidos da América em 2016, ao uso de notícias falsas (BRAGA, 2018, p. 203).
} 
blicações que buscaram explorar a narrativa histórica sem a historicidade necessária é mencionada pelo próprio Jurandir Malerba (2014. p. 38) quando questiona: "aguça a curiosidade intelectual pensar na razão do aparecimento de 'leituras' tão francamente conservadoras numa época como a que vivemos, quando se discute socialmente e se aplicam no Estado diferentes politicas de inclusão racial e social".

O que o historiador não levou em consideração é que desde o final do século $X X$ leituras conservadoras das mais diversas matizes já estavam buscando popularizar suas posturas, teses e posicionamentos, utilizando a velocidade e o anonimato possibilitados pela internet (JESUS, 2006). Esse jogo de informações foi sendo aprimorado ao longo de anos, baseando-se, principalmente, na máxima: "Uma mentira repetida mil vezes torna-se verdade". ${ }^{18} \mathrm{~A}$ partir de tal discurso e contando com a experiência prévia do uso da infovia desde os anos 1990, os movimentos conservadores e, principalmente, de extrema direita, como os negacionistas, foram perspicazes em adaptar a sua prática política e discursiva à era virtual das redes sociais, que estão sendo os principais instrumentos de divulgação e manipulação dos discursos extremados.

Dentro desse cenário pode-se evidenciar o ano 2016 como um dos mais prodigiosos, pois foi o momento de ápice da escalada e da popularização de posturas e de discursos conservadores. De acordo com tal conjuntura em âmbito internacional podemos destacar dois acontecimentos que refletem tal situação, o referendo popular da saída do Reino Unido da União Europeia, resolução que ganhou denominação de Brexit (de Britain e Exit), em 23 de junho de 2016; e a eleição de Donald Trump para presidente dos Estados Unidos, em 8 de novembro do mesmo ano. Nesse sentido pode-se dizer que as estratégias das redes sociais foram decisivas na eleição de Trump:
Pessoas que trabalharam nas estratégias de midias sociais da campanha de Trump alegaram que ele ganhou centenas de vezes mais acesso por um determinado gasto do que a campanha de Clinton, embora o Facebook alegue que não foi bem assim, sem relevar o suficiente para aclarar a história. Se havia um multiplicador, este provavelmente foi aplicado a compras de acesso realizadas [...] por grupos pró-Trump [...] algoritmos não podem se importar e não se importam. Um detalhe interessante que veio à tona um ano depois da eleição é que o Facebook oferecera às campanhas de Clinton e Trump equipes presenciais para ajudá-los a maximizar o uso da plataforma, mas só a campanha do republicano aceitou a oferta [...] (LARNIER, 2018, p. 153-154).

Em escala nacional, o 17 de abril de 2016 nunca vai ser esquecido no Brasil, pois marca o início da tomada de poder institucional pela deposição da então Presidenta Dilma Roussef. Diferente de outras ações de tomada de poder evidenciadas na história brasileira, nesse caso, o impeachment ocorreu sem rupturas institucionais significativas, mas, mesmo assim, abriu caminho para enxergar a ponta do iceberg formado pelos os verdadeiros comandantes do poder no País, a chamada bancada BBB (Boi, Bala e Bíblia - latifundiários, empresários da indústria de armas e lideres evangélicos), grupo conservador e reacionário que há muito tempo já vinha dando as cartas no Congresso e, consequentemente, na política nacional. Os interesses de tal grupo, aliado a uma série de conjunções e fatores internos externos, iniciaram o desmonte do problemático governo petista, ainda em 2015.

Frente às diversas construções políticas que se forjaram após o impeachment de Dilma Roussef, o então Deputado Federal Jair Bolsonaro tornou-se, com seu discurso conservador de extrema direita, como a única opção contra a eleição de um candidato de esquerda no país. Para tanto a estratégia era utilizar as redes sociais:

[...] empresas pagaram cerca de $\mathrm{R} \$ 12$ milhões de reais para que uma série de mensagens falsas contra os candidatos Fernando Haddad,

\footnotetext{
18 A frase é atribuida à Joseph Goebbels, Ministro de Propaganda do governo nazista. No entanto, não há nenhuma evidência certa de ele que tenha sido seu autor, mas a frase simboliza bem a propaganda nazista. Segundo Felipe Molenda Araujo (2018, p. 59) "Hitler colocou Goebbels para comandar o ministério da Propaganda e Otto Dietrich para chefiar e controlar toda a imprensa. Inobstante o papel primordial que este último teve, apenas o primeiro é lembrado pela maioria. Dietrich na tentativa de se livrar da condenação acabou imputando todos os crimes a Goebbels, que já era morto na época do julgamento. A ele se atribui a frase de que uma mentira repetida mil vezes torna-se verdade. Ou quem sabe essa frase seja uma fake news imputada a ele.
} 
do PT e Manuela D'ávila, do PCdoB, fossem espalhadas pelo WhatsApp. Empresas como Havan compraram centenas de milhões de mensagens que foram enviadas num serviço conhecido como "disparo em massa. [...] diversas Fake News foram disseminadas envolvendo a moral e reputação de candidatos à presidência e causas sociais tão discutidas nos últimos anos, tais como respeito à vida e aos direitos das mulheres, da comunidade LGBTQ, entre outros. Por meio dessas informações falsas propagadas, o atual presidente da república, Jair Messias Bolsonaro, durante as eleições, acusou o candidato Fernando Haddad de ser o criador do "Kit Gay" e propor para as escolas uma "ditadura gaysista", influenciando as crianças a serem homossexuais e aceitar a ideologia de gênero a partir de um conjunto de materias compondo o "Kit Gay". Observa-se que a Fake News disseminada pelo atual presidente da república enquanto candidato, teve a intenção de propagandear para a população que o candidato Fernando Haddad e o Partido dos Trabalhadores disponibilizaram kits com produtos que incentivavam práticas de "homossexualismo" entre crianças, financiados com dinheiro público [...] o Kit Gay nunca existiu, o livro Aparelho Sexual e Cia., de Hélène Bruller e Philippe Chapuis, mencionado por Jair Messias Bolsonaro como parte do material que compõe o kit, nunca foi incluido em nenhum programa de educação sexual nas escolas públicas quando Haddad exercia o cargo de Ministro da Educação. O vídeo, com as informações falsas, teve o alcance de cerca de 500 mil visualizações, causando inúmeras polêmicas. ${ }^{19}$

Para apurar e averiguar a credibilidade das denúncias mencionadas e a real responsabilidade de tais grupos na suposta trama politica ideológica, no momento em que escrevemos essas linhas, as empresas citadas estão sendo investigadas pela CPI das Fake News no Congresso Nacional e pela Policia Federal.

Sendo assim, não dificil notar que, na linha de tal proposituras, posturas negacionistas que há duas décadas eram divulgadas a partir de estratégias anônimas, agora estão se renovando, extrapolando a negação Holocausto e extrapolando não só tal tema dentro da disciplina histórica, mas também o campo das Humanidades e atingindo diversas áreas do conhecimento, como por exemplo das Ciências Biológicas, quando "questiona-se a eficácia das vacinas e a negação de que o HIV é o responsável pela AIDS; nas Ciências da Terra, são conhecidos o negacionismo climático e a inquirição até mesmo do formato da Terra". (NAPOLITANO; JUNQUEIRA, 2019, p. 1-2). Discursos que, nesse momento, estão sendo apresentados de forma escancarada, e o que é pior, ganhando legitimidade de política de Estado, principalmente no Brasil, situação verificada, também por Marcia Motta ([2020])

[...] a despeito de tudo que já foi escrito, no Brasil e no exterior, sobre a Ditadura Militar, por exemplo, o presidente insiste em comemorar o 31 de março com o slogan "a revolução democrática de 1964". Ninguém que tenha estudado história e possa formar opinião sólida neste terreno defenderia a ditadura negando seu caráter autoritário. A defesa da censura prévia, da tortura e de torturadores não é nem opinião, nem exercício de liberdade de expressão, é um crime e assim deveria ser tratado. ${ }^{20}$

O fato de hoje o Brasil ter à sua frente um grupo político que fere "os princípios mais básicos do direito à vida, à informação e à cultura [...]" com certeza contribui para tal cenário, pois para eles "a ciência, a história, a Justiça, o Parlamento só têm valor [...] se servem aos seus interesses particulares e muitas vezes obscuros" (MOTTA, [2020]). Coerente com tal postura é que em 24 de abril de 2020 o Presidente da República, Jair Bolsonaro, vetou o projeto de lei que regulamentaria a profissão de historiador, de autoria do senador Paulo Paim (PT). A proposta criada em 2009, tinha sido aprovada pelo Senado em fevereiro do mesmo ano e era resultado de anos de lutas da comunidade de historiadores.

Diante de tal situação entendemos que não podemos mais nos furtar de discutir tais questões e nem de defender o ofício do historiador, pois nesse momento tal iniciativa se mostra de suma relevância no auxilio da manutenção das instituições democráticas do Brasil. Assim, o amparo às especificidades do ofício do historiador ganham

\footnotetext{
19 ARDUINO Luiz Guilherme de Brito; MORAES, Vania de. A transmissão de Fake News como um recurso de propagabilidade durante a campanha eleitoral de 2018. XXIV Congresso de Ciências da Comunicação na Região Sudeste - Vitória - ES Trabalho apresentado na DT 2 - Publicidade e Propaganda do XXIV Congresso de Ciências da Comunicação na Região Sudeste, realizado de 3 a 5 de junho de 2019 Anais [...]. Disponivel em: http://portalintercom.org.br/anais/sudeste2019/resumos/R68-0374-1.pdf. Acesso em: 29 maio 2020.

20 MOTTA, Marcia Maria Menendes. Veto à História: profissão existe com ou sem aval de Bolsonaro. Folha de S. Paulo, São Paulo, 29 abr. 2020. Disponivel em: https://www1.folha.uol.com.br/opiniao/2020/04/veto-a-historia.shtml. Acesso em 10 maio 2020.
} 
cada vez mais urgência, justamente em virtude da atual necessidade de contraposição às práticas narrativas dos negacionistas, que divulgam, vulgarmente, estarem "fazendo história", mas, na verdade, têm entre seus objetivos o proselitismo de causas morais, políticas e ideológicas, comprometidas com iniciativas intolerantes e discriminatórias.

\section{Considerações finais}

Na primeira publicação sobre o tema do negacionismo no Brasil, terminamos o livro atentando para que

o estudo possa ser um instrumento não só de análise historiográfica, mas também de alerta para crescente falta de posicionamento firme da comunidade de historiadores e educadores diante dos usos e abusos que se tem feito em nome do passado (JESUS, 2006, p. 160).

Longe de ser um ato de futurologia, o apelo à comunidade de historiadores foi baseado em evidências e sinais de que posturas extremadas e apropriações do passado com objetivos políticos e ideológicos particulares estavam, já naquele momento, ficando cada vez mais comuns com o uso da infovia. Na época, a utilização e o estudo de fontes oriundas da internet eram vistos com ressalvas por parte da comunidade de historiadores, pois sua materialidade era considerada um tanto quanto fugaz e pouco confiável, talvez resquícios da herança positivista da área que ainda se adaptava e olhava com certa desconfiança para todo documento que não era escrito. Ao longo de duas décadas, o documento digital passou a ser problematizado devido as mesmas especificidades que outrora tinham sido alvo das críticas do historiador. Isso se deu, pois os cientistas das humanidades foram obrigados a enxergar o mundo virtual, já que tal ambiente passou a disputar espaço do cotidiano com o mundo real e material, concretizando-se ao longo dos últimos anos por meio das redes sociais, instrumentos que possibilitaram que a informação fluisse em uma rapidez e um dinamismo nunca vistos até então. A problematização de tais fontes é que auxilia- ram a enxergar que os negacionistas utilizavam várias estratégias para atribuir uma aparência cientíica e legitimadora para suas teses, tais como: inversão de sentido de um dado documento, análise literal de fontes codificadas e, o que é mais comum, alçam à condição de fato, uma série de afirmações que não se apoiam em evidências cientificas, iniciativas mínimas para torná-las confiáveis. Analogamente, valem-se de fontes altamente comprometidas com ideais ligados às tendências políticas e ideológicas de extrema-direita. Assim, as narrativas negacionistas não se sustentam do ponto de vista historiográfico, seja por falta de fontes, seja por comprometimento com fontes de credibilidade duvidosa. Além disso, sua narrativa, pretensamente histórica, se caracteriza por manipular qualquer método de abordagem que dê credibilidade às suas hipóteses.

Fica claro desta forma, que nas inúmeras variações da narrativa negacionista em cada área do conhecimento há o comprometimento com tendências políticas e ideológicas específicas e não com a ciência e com a "verdade histórica", como costumam afirmar seus divulgadores. Por isso, é possível afirmar que os negacionistas podem ser vistos como um grupo mais perniciosos que militantes de extrema direita, neonazistas e nazistas, pois esses últimos deixam claras as suas posições, diferentemente daqueles que, por meio de estratégias variadas, tentam diluir o racismo, a intolerância e o proselitismo no nacionalismo e em um pretenso discurso científico. Só tendo consciência das intenções, é possivel valer-se dos instrumentos da ética e da história para evidenciar a natureza discriminatória desses grupos. Situação essa, que requer dinamismo e urgência da comunidade historiográfica, pois há um aumento das tendências políticas e ideológicas conservadoras e de extrema direita, que cada vez mais passam a ser vistas com uma maior naturalidade dentro de uma conjuntura política e social, a ponto de Michel Lowy ([2014]) afirmar que "esse é um fenômeno sem precedentes desde 1930". Tal situação pode ser confirmada, empiricamente, pela ascensão de 
grupos conservadores em boa parte das maiores economias do mundo. ${ }^{21}$

Se não podemos asseverar que todos esses governos se encaixam na definição de extrema direita, por outro lado, pode-se afirmar que suas posturas - tanto nas politicas internas anti-imigração, como nas externas que tomam como base um discurso intolerante - impulsionam iniciativas de grupos extremados e fascistas. Alguns fatos ilustram tal hipótese, como por exemplo, o atentado contra uma marcha antirracista em Chalottesville, que deixou 3 mortos e 30 pessoas feridas, no Estado da Virgínia, nos Estados Unidos, em agosto de 2017, ou a marcha de extrema direita, contando com 60 mil pessoas em Varsóvia, em novembro do mesmo ano.

Neste sentido, é importante lembrar que a relevância de tal discussão parte de uma dupla preocupação. Primeiro de cidadão, ao notar que tais discursos ligados a um posicionamento xenofóbico e intolerante estão ganhando espaço a ponto de individuos, em nome de uma leitura conservadora da sociedade, desrespeitarem, de forma violenta, as minorias religiosas, as escolhas sexuais e ideológicas, buscando defender a misoginia, o autoritarismo, o antissemitismo, o machismo e o desprezo pela democracia. Segundo a de historiador, baseado na indignação de notar que os acontecimentos históricos estão sendo relativizados sem critérios propriamente históricos, ou seja, de acordo com interesses discriminatórios, políticos, ideológicos e propagandísticos. Assim, manipulando fatos e documentos, os negacionistas tomam a concepção da verdade para si, espoliando a memória e a História. Nesse caso, deve-se destacar a ênfase no problema da "verdade" do conhecimento histórico, que se constituiu em questão central no discurso dos negadores do Holocausto, sendo, por isso, largamente discutida na historiografia. Tal discussão que teve grande repercussão nos anos 1990, agora voltou a ganhar os holofotes da historiografia, mas acompanhado de uma maior repercussão na mídia e com requintes pseudocientíficos, calcados no conceito de "pós-verdade" e "Fake News", por exemplo. Além disso, a dúvida da verdade chegou às outras áreas do saber e foi substituida pela crença na mentira, pois grupos como os negacionistas, divulgam e defendem, cada vez mais, opiniões incrédulas como se fossem fatos. Iniciativa que nos compele a defender, de forma incisiva, algo que foi evidenciado por Hannah Arendt, ainda, nos idos de 1967 de que nunca deve-se esquecer que: "há uma quantia expressiva da verdade que é baseada em fatos e pode ser comprovada e autenticada de forma experimentada e científica".22

Por isso, pode-se dizer que depois de quase duas décadas que marcam a conclusão da primeira pesquisa sobre o negacionismo no Brasil no campo da História (JESUS, 2006, p. 168), tais discursos que desmereciam o ofício do historiador, ainda continuam soando como provocação, só que agora à toda comunidade científica que se tornou alvo da estratégia da intolerância que marca a prática desse grupo.

Por isso, novamente, asseveramos que, neste momento, os historiadores devem se posicionar criticamente, tendo em vista o estabelecimento de uma visão ética e crítica dos fatos, iniciativa essencial em uma época em que essa virtude se encontra tão ameaçada. Como afirmou Jaques Le Goff, (1992, p. 25) uma das tarefas da ciência histórica, "além de estabelecer a relação passado-presente, é acrescentar o horizonte do futuro", e, neste futuro, para o bem da democracia, da ética e dos direitos humanos, não se pode correr o risco da História e dos demais ramos do conhecimento se tornarem instrumento de grupos intolerantes e discriminatórios.

\footnotetext{
${ }^{21}$ LOWY, Michel. Dez teses sobre a ascensão da extrema direita europeia. Folha de S. Paulo, São Paulo, 15 jun.2014. Disponivel em: https://www1.folha.uol.com.br/paywall/adblock.shtml?origin=after\&url=https://m.folha.uol.com.br/ilustrissima/2014/06/146989o-dez-teses-sobre-a-ascensao-da-extrema-direita-europeia.shtml?loggedpaywall. Acesso em: 6 dez. 2017. A situação se agravou, ainda mais, com o crescimento de uma nova direita populista, como a de Donald Trump nos EUA, do partido polonês, Lei e Justiça que obteve não apenas 39\% dos votos, mas a maioria absoluta no Parlamento em 2015 e a eleição de Jair Bolsonaro no Brasil em 2018 (Cf. LOWY, [2014]). 22 O ensaio "Verdade e Política", cujo titulo original é "Truth and Politics" foi publicado pela primeira vez no The New Yorker, em fevereiro de 1967 e integrado no livro Between Past and Future, editado no ano seguinte.
} 


\section{Referências}

ABREU, Alzira Alves de. Um político e dois depoimentos. In: XX ENCONTRO ANUAL DA ANPOCS. Caxambu, Minas Gerais, 22 a 26 de out.1996.

ANSART, P. História e memória dos ressentimentos. In: BRESCIANE, S.; NEXARA, M. (org.). Memória (re) sentimento. Campinas, SP: Editora da Unicamp, 2001.

ARENDT, Hannah. Verdade e política. Entre o passado e o futuro. Tradução de Mauro W. Barbosa de Oliveira. 5. ed. São Paulo: Perspectiva, 2002.

BLOCH, Marc. Apologia da História ou o Ofício de Historiador. Rio de Janeiro: Zahar, 2001.

BOBBIO, Noberto. Direita e esquerda: razões e significados de uma distinção política. São Paulo: Unesp, 1995.

BOLESINA, Iuri; ALVES, Bruno Almir Scariot. A era da pós-verdade: como a informação tem sido relativizada. Disponivel em: https:// webcache.googleusercontent. com/search?q=cache:pC83ftatpwg J:https://soac.imed. edu.br/index.php/mic/xiimic/paper/view/1141/338+\&$c \mathrm{~cd}=11 \& \mathrm{hl}=\mathrm{pt}-\mathrm{BR} \& \mathrm{ct}=\mathrm{clnk} \& \mathrm{gl}=\mathrm{br}$. Acesso em: 03jun. 2020.

BURKE, Peter. A Escola dos Annales (1929-1989): a Revolução Francesa da Historiografia. São Paulo: UNESP, 1997

CARDOSO, Lucileide Costa. Os discursos de celebração da 'Revolução de 1964'. Revista Brasileira de História, São Paulo, v. 31, n. 62, p. 117-140, 2011. https://doi. org/10.1590/S0102-01882011000200008

CEPÊDA, Vera Alves. A Nova Direita no Brasil: contexto e matrizes conceituais. Mediações - Revista de Ciências Sociais, Londrina, v. 23, n. 2, p. 75-122, maio/ago. 2018. Disponivel em: http://www.uel.br/revistas/uel/index.php/ mediacoes/article/view/34801/pdf. Acesso em: $15 \mathrm{jul}$. 2019. https://doi.org/10.5433/2176-6665.2018v23n2p40

CERTEAU, M. A escrita da História 2. ed. Rio de Janeiro: Forense, 2000.

CHARTIER, R. A história hoje: dúvidas e desafios, propostas. Estudos Históricos, Rio de Janeiro, v. 7, n. 13, p. $97-113,1994$

CRUZ, Natália dos Reis Negando a História: a editora revisão e o neonazismo. 1997. 240 p. Dissertação (Mestrado em História) - Universidade Federal Fluminense, Niterói, RJ.

CYTRYNOWICZ, Roney. As formas de lembrar e o estudo do Holocausto. In: MILLMAN, Luis; VIZENTINI, Paulo Fagundes (org.). Neonazismo, Negacionismo e Extremismo Político. Porto Alegre: UFRGS, 2000.

D'ARAUJO, Maria Celina; SOARES, Gláucio Ary Dillon; CASTRO, Celso (org.). Visões do golpe: a memória militar sobre 1964. Rio de Janeiro: Relume Dumará, 1994a.

D'ARAUJO, Maria Celina; SOARES, Gláucio Ary Dillon; CASTRO, Celso. (org.). Os anos de chumbo: A memória militar sobre a repressão. Rio de Janeiro: Relume Dumará, 1994b.

DELGADO, Lucília de Almeida Neves. História oral e narrativa: tempo, memória e identidades. História Oral, São Paulo, n. 6, p. 9-25, 2003.
DIAS, Reginaldo Benedito. A Comissão Nacional da Verdade, a disputa da memória sobre o período da ditadura e o tempo presente. Patrimônio e memória. São Paulo, v. 9, n. 1, p. 71-95, 2013.

DOSSE, F. História em Migalhas. 3. ed. Campinas, SP: Editora Unicamp, 1994.

FERREIRA, Marieta de Moraes. História do tempo presente: desafios. Cultura Vozes, Petrópolis, v. 94, n. 3. p.111-124, maio/jun., 2000.

GINZBURG, Carlo. Solo un testigo. Revista do Instituto Nacional de Antropologia e História, México, n. 32, p. 3-20, abr./set., 1994

HOBSBAWN, Eric. A Era dos Extremos. São Paulo: Companhia das Letras, 1999. p. 393-421.

JESUS, Carlos Gustavo Nóbrega. Antissemitismo e nacionalismo; negacionismo e memória: Revisão Editora e as estratégias da intolerância. São Paulo: UNESP, 2006

LARNIER, Jaron. Dez argumentos para você deletar agora suas redes sociais. Rio de Janeiro: Intrísinca, 2018.

LE GOFF, Jacques. História e memória. Campinas, SP: Editora Unicamp, 1992.

LOWY, Michel. Dez teses sobre a ascensão da extrema direita europeia. Disponivel em: http://www1.folha.uol com.br/ilustrissima/2014/06/1469890-dez-teses-sobre-a-ascensao-da-extrema-direita-europeia.shtml. Acesso em: 6 dez. 2017

MARCHA da extrema-direita reúne 60 mil pessoas na Polônia. Disponivel em: https://oglobo.globo.com/ mundo/marcha-da-extrema-direita-reune-60-mil-pessoas-na-polonia-22060332\#ixzz50gD8KWvP. Acesso em: 6 dez. 2017

MILLMAN, Luis. Negacionismo: gênese e desenvolvimento do extermínio conceitual. In: MILLMAN, Luis: VIZENTINI, Paulo Fagundes (org.). Neonazismo, Negacionismo e Extremismo Político. Porto Alegre: [s. n.], 2000.

MORAES, Luis Edmundo de Souza. O negacionismo e o problema da legitimidade da escrita sobre o passado. In: XXVI SIMPÓSIO NACIONAL DE HISTÓRIA - ANPUH, São Paulo, jul. 2011.

MOTTA, Marcia Maria Menendes. Veto à História: profissão existe com ou sem aval de Bolsonaro. Folha de São Paulo, São Paulo, 29 abr. 2020. Disponivel em: https:// www1.folha.uol.com.br/opiniao/2020/04/veto-a-historia.shtml. Acesso em: 10 maio 2020.

NAPOLITANO, Marcos; JUNQUEIRA, Mary Anne. Negacionismos e Revisionismos: o conhecimento histórico sob ameaça. Sintese dos debates e posicionamentos surgidos no evento promovido pelo Departamento de História da FFLCH / USP - Universidade de São Paulo. Disponivel em: https://edisciplinas.usp.br/pluginfile.php/5207773/mod_folder/content/O/NAPOLITANO\%2C\%20Marcos\%3B\%20JUNQUEIRA\%2C\%20 Mary\%20Anne.\%20Como\%20historiadores\%20e\%20 professores\%20devem\%20lidar\%20com\%20negacionismos\%20e\%20revisionismos.pdf?forcedownload=1. Acesso em: 20 maio 2020. 
NAQUET, Vidal. Os Assassinos da memória Campinas. Editora Unicamp,1987.

NORA, Pierre. Entre memória e história: a problemática dos lugares. Projeto História, São Paulo, n. 10, p. 7-28, dez. 1993

RIOUX, Jean Pierre. A memória coletiva. In: RIOUX, J. P.; SIRINELLI, J. F. (org.). Por uma História Cultural. Lisboa: Estampa, 1998

ROUSSO, Henry. A memória não é mais o que era. In: AMADO, Janaina; FERREIRA, Marieta. (coord.). Usos e abusos de história oral. Rio de Janeiro: FGV, 1998. p. 93-101.

SOUZA, Marina M. Comunicação Negacionismo - 2019. Negacionismos no campo da escravidão e história africana. [S. l.]: [s. n.], 2019.

SALLES, Leonardo Gaspary. Nova Direita ou Velha Direita com Wi-Fi ?: uma interpretação das articulações da "direita" na internet brasileira. Dissertação (Mestrado) -- Universidade Federal de santa Catarina, Programa de Pós-Graduação em Sociologia Política, Florianópolis, 2017.

VILMAR, D. K. A negação dos assassinatos em massa do nacional socialismo: desafios para a ciência e para educação política In: MILLMAN, L.; VIZENTINI, P. F. (org.). Neonazismo, Negacionismo e Extremismo Político. Porto Alegre: UFRGS, 2000.

VIZENTINI, Paulo Fagundes. O ressurgimento da extrema direita e do neonazismo: a dimensão histórica e internacional. In: MILLMAN, L., VIZENTINI, P. F. (org.). Neonazismo, Negacionismo e Extremismo Politico. Porto Alegre: [s. n.], 2000.

WHITE, Hayden. The politics of the Historical interpretation. In: WHITE, Hayden. The Content of the form. Baltimore e Londres: The Johns Hopkins University Press, 1987

\section{Carlos Gustavo Nóbrega de Jesus}

Pós-doutor em História da Arte pela Universidade de Campinas (Unicamp), em Campinas, SP, Brasil; pesquisador no Departamento de História, Estudos Europeus, Arqueologia e Artes (DHEEAA) da Faculdade de Letras da Universidade de Coimbra (FLUC), em Coimbra, Portugal; superintendente da Fundação Pró-Memória de Indaiatuba (FPMI), em Indaiatuba, SP, Brasil.

\section{Edgar Avila Gandra}

Doutor em História pela Universidade Federal do Rio Grande do Sul (UFRGS), em Porto Alegre, RS, Brasil; professor da Universidade Federal de Pelotas (UFPEL), em Pelotas, RS, Brasil.

\section{Endereço para correspondência}

Carlos Gustavo Nóbrega de Jesus

Fundação Pró-Memória de Indaiatuba

Rua Pedro Gonçalves, 477

Jardim Pau Preto 13330-210

Indaiatuba, SP, Brasil

Edgar Avila Gandra

Universidade Federal de Pelotas

Departamento de História NPHR

Rua Alberto Rosa, 154

Centro, 96010770

Pelotas, RS, Brasil 